\title{
PUCUK DAUN MANGGA (Mangifera indica L.) KULTIVAR CENGKIR SEBAGAI PENURUN KADAR GLUKOSA DARAH
}

\author{
YOUNG LEAF MANGO (Mangifera indica L.) CULTIVAR \\ CENGKIR TO REDUCES THE BLOOD GLUCOSE LEVEL
}

\author{
Sarah Permatasari' ${ }^{1)}$, Tri Cahyanto ${ }^{2)}$, Ayuni Adawiyah ${ }^{3)}$, Risda Arba Ulfa ${ }^{4)}$ \\ Jurusan Biologi Fakultas Sains dan Teknologi Universitas Islam Negeri \\ Sunan Gunung Djati Bandung \\ Email: sarahpermatasari808@gmail.com
}

\begin{abstract}
ABSTRAK
Pucuk daun mangga (Mangifera indica L.) memiliki berbagai zat aktif yang berkhasiat sebagai obat antidiabetes salah satunya kandungan senyawa mangiferin yang tinggi. Penelitian ini memiliki tujuan untuk mengetahui pengaruh penggunaan ekstrak pucuk daun mangga kultivar cengkir yang diberikan secara oral dalam menurunkan kadar glukosa darah pada mencit (Mus musculus). Penelitian ini menggunakan 15 ekor mencit dengan 3 ekor per kelompok perlakuan diantaranya kelompok kontrol negatif (hanya diberi suspensi CMC 0,5\%), kontrol positif (tablet metformin 104,65 mg/kg $\mathrm{BB})$, ekstrak pucuk daun mangga $1(105 \mathrm{mg} / \mathrm{kg} \mathrm{BB})$, ekstrak pucuk daun mangga 2 (210 mg/kg BB), dan ekstrak pucuk daun mangga 3 (420 mg/kg BB). Setelah diinduksi fruktosa $20 \%$ secara intravena, kadar glukosa darah mencit diukur pada waktu ke-30, 60, 90, dan 120 menit. Hasil penelitian menunjukkan bahwa ekstrak pucuk daun mangga kultivar cengkir memiliki pengaruh terhadap penurunan kadar glukosa darah mencit yang tinggi dengan dosis terbaik sama dengan kontrol positif (tablet metformin) yaitu ekstrak pucuk daun mangga kultivar cengkir dosis 1 (105 mg/kg BB mencit).
\end{abstract}

Kata kunci: Ekstrak Pucuk Daun Mangga, Fruktosa, Kadar Glukosa Darah, Mangiferin

\begin{abstract}
Young leaves of mango (Mangifera indica L.) have various substances to induce potent antidiabetic activity from the highest mangiferin compounds. The study aim was to prove the effect of decreased blood glucose levels in male mice using the aqueous young leaf extract of mango cultivars cengkir given orally. This study used 15 mice with 3 mice for each treatment group including negative control group (only given $0.5 \%$ suspension of CMC), positive control (metformin $104.65 \mathrm{mg} / \mathrm{kg} \mathrm{B} . \mathrm{W}$ ), young leaf extract of mango 1 (105 mg/kg B.W), young leaf extract of mango $2(210 \mathrm{mg} / \mathrm{kg} \mathrm{B} . \mathrm{W})$, and young leaf extract of mango $3(420 \mathrm{mg} / \mathrm{kg} \mathrm{B.W})$. Blood glucose levels observed after induced $20 \%$ of fructose with intravenous administration, were measured at 30,60, 90, and 120 minutes. The result of this experiment showed that aqueous young leaf extract of mango has the influence to decrease the blood glucose high level of mice with the best dose as same as positive control (metformin tablet) was (105 mg/kg B.W).
\end{abstract}

Keywords: Blood Glucose Level, Fructose, Mangiferin, Young Leaf Extract Of Mango 


\section{PENDAHULUAN}

Salah satu indikator seseorang menderita diabetes mellitus yaitu kadar glukosa darah yang tinggi dan memiliki nilai melebihi normal (Sukmono, 2009). Penyakit diabetes mellitus disebabkan oleh metabolisme lipid, protein dan karbohidrat yang mengalami gangguan. Kondisi hiperglikemia akan berkembang menjadi diabetes mellitus dengan beragam bentuk komplikasi baik secara makro dan mikro (Nugroho, 2006).

Pengobatan diabetes mellitus biasanya diberi obat oral antidiabetik atau insulin yang jika diberikan secara terus menerus dapat menghabiskan biaya yang besar dan menjadi beban berat bagi penderitanya (Arjadi and Mustofa, 2017). Banyak dari penderita diabetes mellitus berusaha mengendalikan kadar glukosa darahnya dengan menggunakan cara tradisional yaitu dengan tanaman herbal (Prameswari and Widjanarko, 2014). Obat herbal ini memiliki banyak keuntungan diantaranya mudah diperoleh, harga murah dan efek samping relatif kecil (Dalimartha, 2008).

Tanaman obat yang dapat digunakan sebagai obat penurun kadar glukosa darah salah satunya ialah pucuk daun mangga (Mangifera indica L.). Mangga merupakan buah tropis dengan Famili Anacardiaceae (Vega et al., 2017). Di Indonesia, daun muda pada tanaman mangga sering dimakan sebagai salad atau lauk makan (Prommajak et al., 2014). Sedangkan di India pucuk daun mangga telah banyak digunakan sebagai etnomedisin untuk diabetes (Sarmah and Hazarika, 2012).

Pada beberapa penelitian daun mangga terbukti memiliki kandungan sebagai farmakologi yaitu mangiferin yang berkhasiat sebagai zat antidiabetik ataupun penurun kadar glukosa darah (Min et al., 2017). Mangiferin merupakan polyphenol tipe glycosyl xanthone (Takeda et al., 2007). Matkowski et al. (2013), menunjukkan mangiferin sebagai produk alami analgesik, antidiabetik, antisklerotik, antimikroba, antivirus, jantung, hepatoprotektif, antialergi, inhibitor monoamine oxygenase (MAO), dan perlindungan terhadap sinar radiasi UV. Pada mangga, mangiferin dapat diambil dari bagian daun, kulit batang, kulit buah, akar, kulit buah mentah ataupun matang, dan pulp (Jyotshna and Shanker, 2016).

Penelitian sebelumnya pada mencit dan tikus yang dikondisikan diabetes, kadar glukosa darah secara signifikan setelah diberikan ekstrak daun mangga. Penelitian yang dilakukan Ilham et al. (2015), bahwa mencit yang yang diberi dosis 8,4 mg/20 g BB 
ekstrak daun mangga arumanis menurunkan kadar glukosa darah hingga 104,4 mg/dL. Menurut penelitian yang dilakukan oleh Petchi et al. (2011), tikus Wistar yang dikondisikan diabetes diberi ekstrak daun mangga dosis $200 \mathrm{mg} / \mathrm{kg}$ selama 21 hari memiliki hasil paling baik daripada tikus yang diberi ekstrak dosis $100 \mathrm{mg} / \mathrm{kg}$. Hal tersebut juga dibenarkan oleh penelitian yang dilakukan Sudha and Rajalakshmi (2017), bahwa pemberian ekstrak mangga membuat tikus yang diinduksi diabetes memiliki kadar glukosa darah menuju normal.

Pada penelitian ini digunakan pucuk daun mangga sehingga diharapkan daun tersebut memiliki kandungan penurun kadar glukosa darah yang tinggi. Seperti yang dituliskan dalam jurnal Nayak and Subrata (2013), mangiferin dapat diekstraksi dari daun muda (172 g/kg), kulit kayu (107 g/kg), dan daun tua $(94 \mathrm{~g} / \mathrm{kg})$. Hal tersebut juga dibenarkan oleh penelitian Ramirez et al. (2016), bahwa kadar mangiferin tertinggi pada daun mangga yaitu pada daun yang masih muda atau pucuk daun.

Penggunaan daun sebagai pengobatan tradisional banyak digunakan yaitu sekitar 56,25\% karena banyaknya manfaat dan kelimpahan daun di alam (Rahman, 2015). Begitu pula kultivar yang dimiliki oleh mangga, lebih dari 1000 tersebar di seluruh dunia (Vega et al., 2017), termasuk Indonesia. Sementara menurut Cahyanto et al. (2017), di Subang saja ditemukan sebanyak 21 kultivar diantaranya Manalagi, Arumanis, Cengkir dan Madu Keraton. Di Indonesia, penelitian tentang pengujian mangga sebagai antidiabetes masih terbatas pada mangga kultivar arumanis (Ilham et al., 2015) dan bapang (Fithriyani et al., 2014). Oleh karena itu, perlu adanya penelitian tentang uji aktivitas penurun kadar glukosa darah pada mangga dengan kultivar lain salah satunya yaitu mangga kultivar cengkir.

\section{METODE}

\section{Waktu dan Tempat}

Pelaksanaan penelitian dilakukan bulan Maret 2018. Pucuk daun mangga kultivar cengkir dikumpulkan dari Rancaekek. Pemeliharaan hewan uji, pembuatan ekstrak pucuk daun mangga (Mangifera indica L.) kultivar cengkir, dan pengujian terhadap hewan uji dilakukan di Laboratorium Biosistematika dan Perkembangan Hewan Uji Jurusan Biologi Fakultas Sains dan Teknologi, UIN Sunan Gunung Djati Bandung. 


\section{Alat dan Bahan}

Alat yang digunakan meliputi alat gavage, baki, batang pengaduk, beaker glass $100 \mathrm{~mL}$, blender (Philips), gelas ukur $100 \mathrm{~mL}$, glukometer (Autocheck), jarum lancet (OneMed), kawat penutup kandang, kompor, lumpang dan alu, neraca analitik, penangas air, syringe $1 \mathrm{~mL}$, dan tabung falcon.

Bahan yang digunakan meliputi aquades, alkohol 70\%, CMC, kapas, kertas label, kertas saring, mencit 15 ekor, pakan B2 551, sarung tangan, simplisia kering pucuk daun mangga (Mangifera indica L.) kultivar cengkir, serbuk kayu, strip cek kadar gula darah (Autocheck), tablet metformin, dan tissue.

\section{Prosedur Kerja}

\section{Pembuatan Simplisia Pucuk Daun Mangga (Mangifera indica L.) Kultivar Cengkir}

Pucuk daun mangga (Mangifera indica L.) kultivar cengkir dikumpulkan dari Rancaekek Kabupaten Bandung dalam keadaan segar, dibersihkan dengan menggunakan air mengalir dan dikeringkan dengan cara diangin-angin selama 1 minggu pada suhu ruang $\left(25^{\circ} \mathrm{C}\right)$. Selanjutnya sampel yang telah kering dihaluskan sampai menjadi serbuk menggunakan blender.

\section{Pembuatan Ekstrak Pucuk Daun Mangga (Mangifera indica L.) Kultivar Cengkir}

Pembuatan ekstrak pucuk daun mangga dilakukan dengan metode dekoksi atau perebusan. Menurut Warpur (2016), praktik pengolahan tumbuhan yang efektif dijadikan sebagai obat berbagai penyakit biasanya dilakukan dengan cara direbus dan air rebusannya diminum. Simplisia kering yang akan dibuat ekstrak, terlebih dahulu ditimbang sesuai konsentrasi yang akan diberikan, lalu direbus menggunakan air sebanyak $100^{\circ} \mathrm{C}$ selama 5 menit. Kemudian ekstrak disaring menggunakan kertas saring.

\section{Pembuatan Larutan Fruktosa $20 \%$}

Fruktosa ditimbang sebanyak 20 gr. Lalu dilarutkan dalam aquades sebanyak $100 \mathrm{~mL}$, diaduk hingga homogen.

\section{Pembuatan Suspensi CMC 0,5\%}

CMC ditimbang sebanyak 0,5 gr. Lalu didispersikan dalam lumpang berisi 50 $\mathrm{mL}$ aquades panas, diaduk hingga homogen, dan aquades dicukupkan hingga $100 \mathrm{~mL}$. 


\section{Pembuatan Larutan Metformin 104,65 mg/kg BB}

Tablet metformin dihaluskan menggunakan lumpang dan alu, ditimbang sebanyak 45,5 mg lalu dilarutkan dalam suspensi CMC 0,5\% sebanyak $10 \mathrm{~mL}$, diaduk hingga homogen.

\section{Persiapan Hewan Uji}

Mencit jantan berumur 6 minggu dengan berat badan 25 g sebanyak 15 ekor diaklimatisasi selama 1 minggu dalam kandang yang diberi penutup kawat untuk proses adaptasi terhadap lingkungan barunya. Mencit diberi pakan standar berupa pellet (B2 551) dan minum secara ad libitum. Alas kandang dilapisi serbuk kayu.

\section{Penginduksian Fruktosa $20 \%$}

Mencit terlebih dahulu tidak diberi pakan dan minum selama 18 jam. Lalu kadar glukosa darah puasa tersebut diperiksa keesokan harinya. Setelah itu, diinduksi menggunakan fruktosa $20 \%$ dengan cara pemberian intravena sebanyak $0,1 \mathrm{~mL} / 10 \mathrm{gr}$ BB mencit.

\section{Pengukuran Kadar Glukosa Darah}

Ujung ekor mencit dibersihkan menggunakan kapas yang diberi alkohol 70\%, ditusuk menggunakan jarum lancet sampai darah keluar lalu diteteskan pada strip glukometer. Setelah itu, strip ditempelkan di alat glukometer dan hasil dari pembacaan ditunggu sampai 5 detik untuk mengetahui konsentrasi kadar glukosa darah pada layar glukometer (dalam satuan mg/dL) (Soemardji, 2004). Kadar glukosa darah diukur pada 0 menit sebagai kadar glukosa darah puasa, 30 menit sebagai kadar glukosa darah setelah induksi fruktosa, 60, 90, dan 120 menit sebagai kadar glukosa darah setelah diberi perlakuan ekstrak.

\section{Pemberian Sediaan Perlakuan}

Setelah induksi fruktosa, mencit diberikan sediaan menurut kelompok dan dosis yang telah ditetapkan (dosis $1105 \mathrm{mg} / \mathrm{kg} \mathrm{BB}$, dosis $2210 \mathrm{mg} / \mathrm{kg} \mathrm{BB}$, dan dosis 3 $420 \mathrm{mg} / \mathrm{kg} \mathrm{BB}$ ). Pemberian sediaan dilakukan dengan cara per oral sebanyak 1 kali. 


\section{HASIL DAN PEMBAHASAN}

Untuk mengetahui pengaruh dari pemberian sediaan ekstrak pucuk daun mangga (Mangifera indica L.) kultivar cengkir dalam menurunkan kadar glukosa darah mencit yang diinduksi menggunakan fruktosa 20\%, dilakukan pemberian 3 (tiga) perlakuan dosis bertingkat (Gambar 1.)

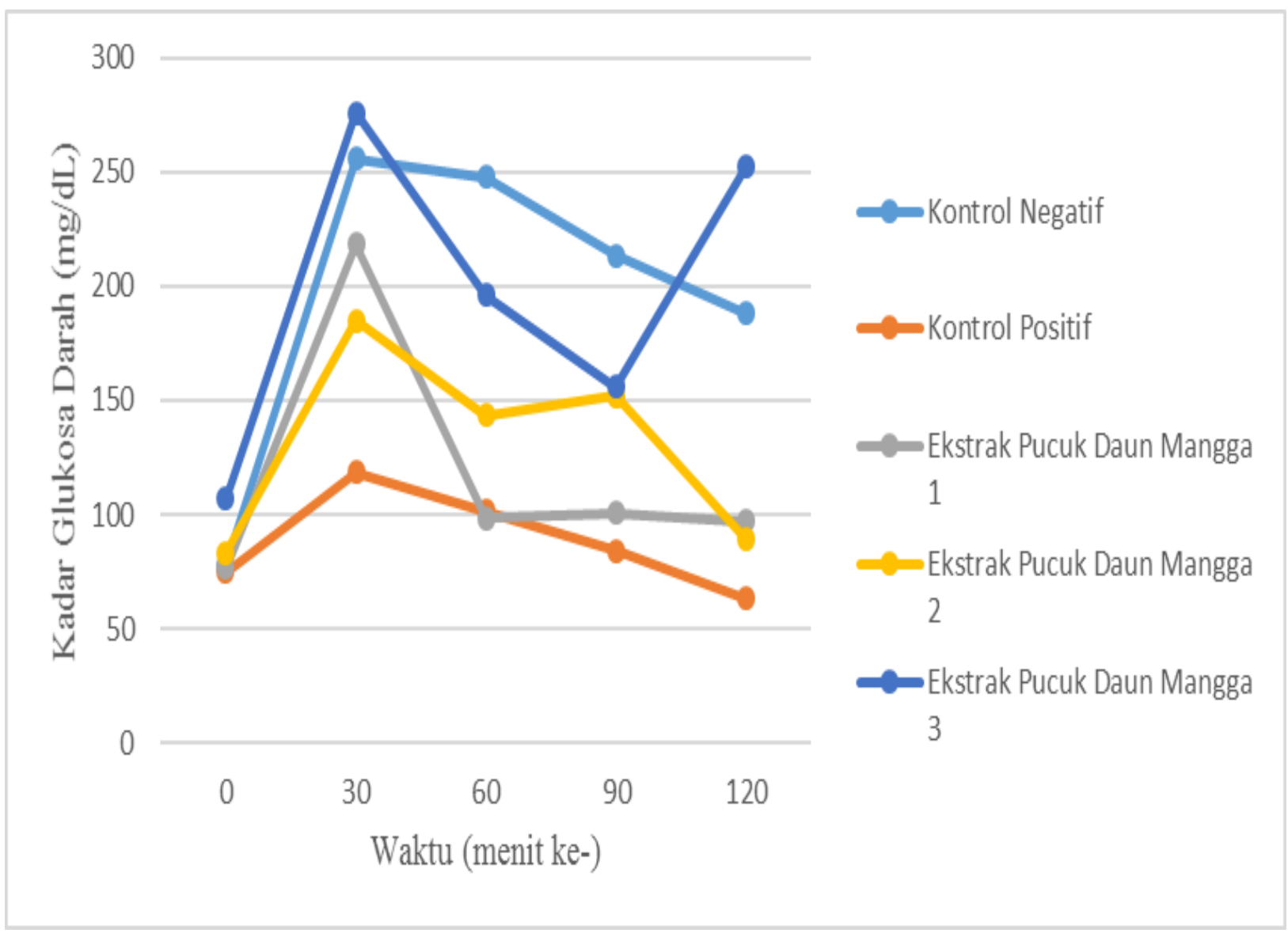

Gambar 1. Penurunan Kadar Glukosa Darah Pada Mencit

Keterangan:

Menit ke-0: kadar glukosa darah awal (puasa) sebelum diinduksi fruktosa pada menit ke-0

Menit ke-30: kadar glukosa darah setelah diberikan induksi fruktosa setelah menit ke-30

Menit ke-60: kadar glukosa darah setelah diberikan induksi fruktosa setelah menit ke-60

Menit ke-90: kadar glukosa darah setelah diberikan induksi fruktosa setelah menit ke-90

Menit ke-120: kadar glukosa darah setelah diberikan induksi fruktosa setelah menit ke120

Setelah pemberian sediaan, pada kelompok kontrol negatif yang hanya diberi CMC 0,5\% kadar glukosa darah cenderung mengalami penurunan namun kadarnya masih dalam keadaan tinggi. Hal ini disebabkan karena CMC 0,5\% yang diberikan tidak 
memberikan pengaruh terhadap kadar glukosa darah karena fungsinya sebagai pelarut dan tidak memiliki senyawa aktif yang dapat menurunkan kadar glukosa darah.

Kelompok kontrol positif diberikan sediaan tablet metformin menunjukkan penurunan pada menit ke-60 hingga 120 dari 101,3 sampai $63 \mathrm{mg} / \mathrm{dL}$. Pemilihan obat pembanding ini didasarkan pada mekanisme yang sama dengan sediaan uji yaitu zat antihiperglikemik oral golongan biguanid mampu menambah sensitivitas insulin dan menekan produksi glukosa hati sehingga kadar glukosa dalam darah menurun dan secara tidak langsung dapat mengurangi pembentukan senyawa oksigen reaktif akibat hiperglikemia (Tatto et al., 2017).

Kelompok perlakuan ekstrak pucuk daun mangga $105 \mathrm{mg} / \mathrm{kg} \mathrm{BB}$ mengalami penurunan pada menit ke-60 sampai dengan 120 dari 98,3-97 mg/dL. Hal tersebut menunjukkan bahwa ekstrak pucuk daun mangga $105 \mathrm{mg} / \mathrm{kg}$ BB memiliki aktivitas penurun kadar glukosa darah yang sebanding dengan metformin dengan dosis 104,65 $\mathrm{mg} / \mathrm{kg}$ BB karena pada dosis ini tidak menunjukkan perbedaan signifikan pada kelompok kontrol positif. Penurunan pada dosis ini sebanyak 121,6 mg/dL.

Pada perlakuan ekstrak pucuk daun mangga 2 kadar glukosa darah mengalami penurunan pada menit ke-60 (143,5 mg/dL), naik pada menit ke-90 $152 \mathrm{mg} / \mathrm{dL})$ dan menit ke-120 kembali turun menjadi 89 mg/dL. Penurunan pada dosis ini sebanyak 96 mg/dL. Pada ekstrak pucuk daun mangga 3 penurunan terjadi pada menit ke-60 (196 mg/dL) dan menit ke-90 (156 mg/dL) dan menit 120 kembali kembali naik menjadi 253 $\mathrm{mg} / \mathrm{dL}$. Kadar glukosa darah pada dosis ini turun sebanyak $23 \mathrm{mg} / \mathrm{dL}$. Adanya penurunan kadar glukosa darah pada hewan uji diakibatkan dengan adanya sekresi insulin dari sel $\beta$ pankreas yang masih dapat bekerja secara normal, tetapi jumlah insulin yang dikeluarkan tidak sebanding dengan kadar glukosa yang terlalu tinggi sehingga penurunan kadar glukosa darah tidak signifikan (Dianasari and Fifteen, 2015).

Pemberian dosis ekstrak pucuk daun mangga memiliki pengaruh dalam turunnya kadar glukosa darah pada mencit dengan hasil yang beragam tergantung dari perlakuan yang diberikan kepada mencit dan konsentrasi senyawa aktif yang terkandung didalam setiap sampel berbeda-beda. Menurut Pakaya et al., (2015), bahwa peningkatan dosis ekstrak tidak serta merta meningkatkan efektivitasnya dalam menurunkan kadar glukosa darah, namun dengan meningkatnya dosis peningkatan respon penurunan kadar glukosa darah menurun. Sehingga penambahan dosis baik 210 
$\mathrm{mg} / \mathrm{kg} \mathrm{BB}$ dan $420 \mathrm{mg} / \mathrm{kg} \mathrm{BB}$ tidak terlalu berpengaruh dalam menurunkan kadar glukosa darah.

Kadar glukosa darah tinggi pada mencit dapat turun disebabkan karena pucuk daun mangga memiliki senyawa aktif yang berkhasiat dalam penurunan kadar glukosa darah yaitu adanya kadar phenol dan flavonoid yang tinggi (Sudha and Rajalakhsmi, 2017), salah satunya yaitu zat mangiferin. Menurut Yoshikawa et al. (2001), zat mangiferin dapat menghambat kerja enzim yang terlibat dalam pencernaan karbohidrat menjadi gula sederhana didalam usus seperti sukrase, isomaltase, dan maltase pada tikus. Dengan demikian, mangiferin mengurangi tingginya kadar glukosa darah dengan mekanisme menghambat penyerapan glukosa.

\section{KESIMPULAN DAN SARAN}

Ekstrak pucuk daun mangga (Mangifera indica L.) kultivar cengkir memliki aktivitas dalam penurunan kadar glukosa darah. Ekstrak pucuk daun mangga kultivar cengkir dengan dosis ke-1 (105 mg/kg BB) merupakan dosis optimal dalam penurunan kadar glukosa darah pada mencit yang diinduksi dengan menggunakan fruktosa.

Perlu dilakukan uji fitokimia lebih lanjut terhadap kandungan senyawa mangiferin dan senyawa lainnya pada pucuk daun mangga kultivar cengkir dan kultivar lain. Juga perlu dilakukan penelitian lanjutan perihal pengaruh ekstrak pucuk daun mangga (Mangifera indica L.) kultivar cengkir terhadap penurunan kadar glukosa darah.

\section{DAFTAR PUSTAKA}

Arjadi, F., \& Mustofa. (2017). Ekstrak Daging Buah Mahkota Dewa Meregenerasi Sel Pulau Langerhans Pada Tikus Putih Diabetes. Biogenesis. 5(1): 27-33. P-ISSN: 2302-1616, E-ISSN: 2580-2909.

Cahyanto, T., Ahmad, S., Muhammad, E., \& Ida, K. (2017). The Diversity Of Mangifera indica Cultivars In Subang West Java Based On Morphological And Anatomical Characteristics. Biosaintifika. 9(1): 156-167. P-ISSN: 2085191X, E-ISSN: 2338-7610.

Dalimartha, S. (2008). Ensiklopedia Tanaman Obat Indonesia 5. Dinamika Media. Jakarta. 
Dianasari, D., \& Fifteen, A. F. (2015). Uji Aktivitas Antidiabetes Ekstrak Air Kelopak Bunga Rosella (Hibiscus sabdariffa L.) Pada Tikus Dengan Metode Induksi Aloksan. Jurnal Farmasi Sains Dan Terapan. 2(1): 54-59.

Fithriyani, L. N., Dhadhang, W. K., \& Eka, P. N. R. (2014). Formulasi Tablet Mukoadesif Ekstrak Etanol Daun Mangga Bapang (Mangifera indica L. 'Bapang') Sebagai Antidiabetes Menggunakan Matriks Guar Gum. Jurnal Ilmu Kefarmasian Indonesia. 12(2): 176-183. ISSN: 1693-1831.

Ilham, M. S., Suwendar, \& Lanny, M. (2015). Uji Aktivitas Antidiabetes Ekstrak Etanol Daun Mangga Arumanis (Mangifera indica L. “Arumanis”) Pada Mencit Swiss Webster Jantan Dengan Metode Tes Toleransi Glukosa Oral (TTGO). Prosiding Penelitian SPeSIA Unisba. 297-314. ISSN: 2460-6472.

Jyotshna, K. P., \& Shanker, K. (2016). Mangiferin: A Review Of Sources And Interventions For Biological Activities. BioFactors. 42(5): 504-514.

Matkowski, A., Kus, P., Goralska, E., \& Wozniak, D. (2013). Mangiferin - A Bioactive Xanthonoid, Not Only From Mango And Not Just Antioxidant. Mini-Rev. Med. Chem. 13(3): 439-455.

Min, Q., Xinpei, C., Weiguang, S., Fei, G., Zhimei, L., Qian, Z., Luo-Sheng, W., Hua, L., \& Jiachun, C. (2017). Identification Of Mangifeirn As A Potential Glucokinase Activator By Structure-Based Virtual Ligand Screening. Nature Scientific Reports. 7(44681): 1-9.

Nayak, A., \& Subrata, D. (2013). Antidiabetic Potential Medicinal Plants. BioMedRX. 1(1): 32-46.

Nugroho, A. E. (2006). Hewan Percobaan Diabetes Mellitus: Patologi Dan Mekanisme Aksi Diabetogenik. Biodiversitas. 7(4): 378-382. ISSN: 1412-033X.

Pakaya. I., Widysusanti, A., \& Hamsidar, H. (2015). Uji Aktivitas Antidiabetes Ekstrak Biji Pinang (Areca catechu L.) Terhadap Mencit Jantan Yang Diinduksi Glukosa. Artikel Farmasi Kesehatan dan Keolahragaan. 1-12.

Petchi, R. R., Parasurman, S., Vijaya, C., Girish, D., \& Devika, G. S. (2011). Antidiabetic Effect Of Kernel Seeds Extract Of Mangifera indica (Anacardiaceae). International Journal Of Pharma And Bio Sciences. 2(1): 385-393. ISSN: 0975-6299. 
Prameswari, O. M., \& Widjanarko, S. B. (2014). Uji Efek Ekstrak Air Daun Pandan Wangi Terhadap Penurunan Kadar Glukosa Darah Dan Histologi Tikus Diabetes Mellitus. Jurnal Pangan dan Agroindustri. 2(2): 16-27.

Prommajak, T., Sang, M. K., Cheol-Ho, P., Sang, M. K., Suthat, S., \& Nithiya, R. (2014). Identification Of Antioxidants In Young Mango Leaves By LC-ABTS dan LC-MS. CMU J. Nat. Sci. 13(3): 317-330.

Rahman, A. H. M. M. (2015) Traditional Medicinal Plants In The Treatment Of Important Human Diseases Of Joyhurpat District, Bangladesh. Journal Of Pharmaceutical Biological And Chemical Sciences. 2(1): 21-29. ISSN: 23943076.

Ramirez, N. M., Leticia, M. F., Francine, A. S., Joao, P. V. L., Maria, I. D. S. D., Renata, C. L. T., Jose, H. D. Q., Hercia, S. D. M., \& Sonia, M. R. R. (2016). Extraction Of Mangiferin And Chemical Characterization And Sensorial Analysis Of Teas From Mangifera indica L. Leaves Of The Uba Variety. Beverages. 2(33): 1-13.

Sarmah, P. C., \& R. Hazarika. (2012). Evaluation Of Hypoglicemic Effect Of Mangifera Leaf. International Journal Of Applied Biology And Pharmaceutical Technology. 3: 98-102.

Soemardji, A. A. (2004). Penentuan Kadar Gula Mencit Secara Cepat: Untuk Diterapkan Dalam Penapisan Aktivitas Anti Diabetes In Vivo. Acta Pharmaceutical Indonesia. 29(3): 115-116.

Sudha, A. M., \& Rajalakshmi, M. (2017). Evaluation Of Antidiabetic Activity Of Aqueous Extract Of Mangifera indica Leaves In Alloxan Induced Diabetic Rats. Biomedical And Pharmacology Journal. 10(2): 1029-1035.

Sukmono, R. J. (2009). Mengatasi Aneka Penyakit Dengan Terapi Herbal. AgroMedia Pustaka. Jakarta.

Takeda, T., Tsubaki, M., Kino, T., Yamagishi, M., Iida, M., Itoh, T., Imano, M., Tanabe, G., Muraoka, O., Satou, T., \& Nishida, S. (2007). Mangiferin Induces Apoptosis In Multiple Myeloma Cell Lines By Suppressing The Activation Of Nuclear Factor Kappa B-Inducing Kinase. Chem. Biol. Interact. 1:26-33.

Tatto, D., Niluh, P. D., \& Feiverin, T. (2017). Efek Antihiperkolesterol Dan Antihiperglikemik Ekstrak Daun Ceremai (Phyllantus acidus (L.) Skeels) Pada 
Tikus Putih Jantan (Rattus norvegicus) Hiperkolesterol Diabetes. Jurnal Farmasi Galenika. 3(2): 157-164. ISSN: 2442-8744.

Vega, J. A. I., Jose, A. M. G., Manuel, S. G., Gabriel, B. C., Sara, M. S. D., Maria, T. S. M., Angel, M. G., Rogelio, P. B., Eduardo, M. B., \& Eduardo, M. S. (2017). Evidence Of Some Natural Product With Antigenotoxic Effects Part 1: Fruits And Polysaccharides. Journal Nutrients. 9(102): 1-27.

Warpur, M. (2016). Struktur Vegetasi Hutan Mangrove Dan Pemanfaatannya Di Kampung Ababiaidi Distrik Supiori Selatan Kabupaten Supiori. Jurnal Biodjati. 1(1): 19-26. ISSN: 2541-4208.

Yoshikawa, M., Nishida, N., Shimoda, H., Takada, M., Kawahara, Y., \& Matsuda, H. (2001). Polyphenol Constituents From Salacia Species: Quantitative Analysis Of Mangiferin With Glucosidase And Aldose Reductase Inhibitory Activities. J. Pharmac. Soc. Jap. 121: 371-378. 